\title{
A INFLUÊNCIA DA LIDERANÇA POLÍTICA NOS PLANOS BRASILEIROS DE ESTABILIZAÇÃO ECONÔMICA: DO CRUZADO AO REAL
}

\author{
JUNIOR IVAN BOURSCHEID ${ }^{\dagger}$ \\ RODRIGO STUMPF GONZÁLEZ ${ }^{\dagger \dagger}$ \\ RODOLFO SILVA MARQUES ${ }^{\dagger \dagger \dagger}$
}

RESUMO: O presente trabalho pretende analisar de forma sintética as relações político-econômicas que marcaram o planejamento para a estabilização econômica do Brasil no período entre a implementação do Plano Cruzado, em 1986, e do Plano Real, por volta de 1993 e 1994. Para

\footnotetext{
† Doutorando do Programa de Pós-Graduação em Ciência Política da Universidade Federal do Rio Grande do Sul (UFRGS), Mestre em Ciência Política pela UFRGS, 2016, Bacharel em Relações Internacionais pela Universidade Federal de Santa Maria (UFSM), 2014. Bolsista do Conselho Nacional de Desenvolvimento Científico e Tecnológico (CNPq). Pesquisador membro do Núcleo Pesquisa em Relações Internacionais (PRISMA), e Vice-Líder do Grupo de Teoria, Arte e Política (GTAP) do Núcleo PRISMA. 2oㅗ Secretário do Centro de Integração Latino Americana (CILAM). † Graduação em Direito pela Universidade Federal do Rio Grande do Sul (UFRGS), 1988, Mestrado em Ciência Política pela UFRGS, 1994, e Doutorado em Ciência Política pela UFRGS, 2000. Professor Adjunto do Departamento de Ciência Política da UFRGS. Bolsista de produtividade em pesquisa e consultor ad hoc do Conselho Nacional de Desenvolvimento Científico e Tecnológico (CNPq) e consultor da Coordenação de Aperfeiçoamento de Pessoal de Nível Superior (CAPES).

†† Doutorando em Ciência Política pela Universidade Federal do Rio Grande do Sul (UFRGS), Mestre em Ciências Políticas e Relações Internacionais na Universidade Federal do Pará (UFPA), 2008-2010. Graduação em Comunicação Social - Publicidade e Propaganda pela Universidade da Amazônia (UNAMA), 2001, e em Gestão e Produção de Eventos Culturais pela UNAMA, 2003. Pós-Graduação em Marketing, pela Fundação Getúlio Vargas (FGV), 2001-2003. Coordenador do Curso de Comunicação Social da Faculdade de Estudos Avançados do Pará (FEAPA) durante o biênio 2011-2012. Professor Adjunto da UNAMA e da FEAPA. Professor da PósGraduação Lato Sensu da UNAMA, Curso de Pós-Graduação Lato Sensu em Jornalismo, Cidadania e Políticas Públicas e Curso de Pós-Graduação Lato Sensu em Gestão de Marketing. Professor-Convidado e Orientador de Artigos da CPÓS/ESAMAZ.
} 
tanto, foi feito o uso da pesquisa qualitativa e de cunho histórico, compreendendo-se, nos aspectos políticos e institucionais, alguns elementos relevantes para a apreensão das limitações e perspectivas à aplicabilidade das políticas econômicas surgidas com a redemocratização, visando a superação da crise econômica que permeou o início do processo de transição para o regime democrático. Utilizando o enfoque da teoria neo-estruturalista da inflação inercial, observamos a importância do apoio político para o controle gradual da inflação, com a indexação completa da economia, bem como a necessidade de uma reforma fiscal que permita a manutenção das medidas de controle inflacionário. De tal modo, foi evidenciado que foram aspectos relevantes tanto a falta de um diagnóstico preciso sobre o tipo de inflação, quanto as condicionantes políticas para a otimização das medidas antiinflacionárias, em um cenário de recente institucionalização democrática e conformação de novos compromissos políticos almejando consolidar alianças que permitissem garantir a governabilidade.

Palavras-Chave: Planos Econômicos; Estabilização; Medidas AntiInflacionárias; Liderança Política. 
ABSTRACT: This paper briefly discusses the political-economic relationships that marked the planning to economic stabilization in the Brazilian New Republic government, specifically in the period between the implementation of the "Cruzado Plan", in 1986, and the Real Plan, through 1993 and 1994. Therefore, we used qualitative research, within historical profile. The article encompasses some relevant elements in the political and institutional to understand perspectives and limitations to the applicability of the economic policies arising from the democratization, aimed at overcoming the economic crisis that permeates the beginning of the transition to democracy. Using the neo-structuralist approach of inertial inflation, it's observed the political support's importance to the gradual control of inflation, with the complete economic indexation, as well the necessity of an fiscal reform that permit the maintenance of the inflationary measures control. Thus, it's showed that both the lack of an accurate diagnosis of the type of inflation and the political conditions to the utilization of anti-inflationary measures were relevant factors, in a scenario of recent democratic institutionalization and forming new political commitments aiming to consolidate alliances which ensure governability.

KEYWORDS: Economic Plans; Stabilization; Anti-Inflationary Measures; Political Leadership. 


\section{SUMÁRIO:}

I. INTRODUÇÃO .............................................................................................405

II. A INTERAÇÃO DE FATORES POLÍTICOS E ECONÔMICOS

NOS PLANOS DE ESTABILIZAÇÃO.....................................................409

1. Governo Sarney: a busca por apoio popular e parlamentar ...........................................................................409

2. Governo Collor: insulamento burocrático e isolacionismo..........................................................................419

3. Governos Itamar e Cardoso: a estabilização como plataforma eleitoral e governamental ....................................427

III. CONCLUSÃO ..............................................................................................431

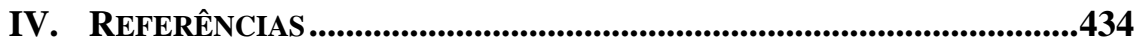

\section{TABLE OF CONTENTS:}

I. INTRODUCTION ...........................................................................................405

II. THE INTERACTION BETWEEN POLITICAL AND ECONOMIC FACTORS

IN BRAZILIAN STABILIZATION PLANS ...............................................409

1. Sarney Administration: the search for popular and parliamentary support.................................................................409

2. Collor Administration: bureaucratic insulation and isolationism ...................................................................................419

3. Itamar and Cardoso Administrations: the stabilization as electoral and governmental platforms ..................................427

III. CONCLUSION ..................................................................................................4331

IV. REFERENCES ….............................................................................................434 


\section{INTRODUÇÃO}

Antes de se analisar a conjuntura de acontecimentos da Nova República, no que tange à perspectiva político-econômica dos planos de estabilização econômica, cabe compreender o contexto no qual a mesma gestou-se. Para isso, regressamos temporalmente ao momento em que a inflação, enfoque central das ações governamentais no novo período democrático brasileiro, começa a apresentar um aumento progressivo, na década de 1960.

Um pouco antes, na segunda metade dos anos 1950, com o Plano de Metas (1955-1961), deflagrado pelo então Presidente Juscelino Kubitscheck, verificou-se que sua viabilização tinha dificuldades no seu próprio financiamento. Para a execução do Plano de Metas, houve claramente um aumento nos gastos públicos por meio de investimentos em obras de infraestrutura, que por sua vez foram financiados por emissão monetária, resultando em um processo de aceleração inflacionária. ${ }^{1}$

É possível identificar um paralelismo entre os processos de industrialização e de aceleração inflacionária, atingindo seu auge em meados dos anos 1960. Após visualizar-se certa contenção no final dos anos 1960 e início dos anos 1970, a inflação aumenta sobremaneira nos anos 1980, atingindo seus maiores patamares no início da década de $1990 .^{2}$

De acordo com Gremaud, Vasconcellos e Toneto Jr. ${ }^{3}$, o processo de significativo aumento da taxa de inflação parecia estar relacionado, tanto a choques internos, quanto a externos - como os dois choques do petróleo (1973 e 1979), choques das taxas de juros internacionais, quebras de safra, alterações cambiais, entre outros - e sua propagação estava atrelada aos mecanismos formais e informais de indexação da economia. Tal

${ }^{1}$ Cf. GREMAUD, Amaury Patrick; VASCONCELLOS, Marco Antonio Sandoval de; TONETO JR. Rudinei. Economia Brasileira Contemporânea. $7^{a}$ ed. São Paulo, SP: Atlas, 2007.

2 Os dados da evolução do processo inflacionário no século XX, em taxas médias por décadas, apresentam-se da seguinte maneira: 1900: -2\%; 1910: 7\%; 1920: 3\%; 1930: 2\%; 1940: 13\%; 1950: 21\%; 1960: 45\%; 1970: 37\%; 1980: 605\%; 1990-1995: 1270\%; 1996-2000: 7\%. Cf. GREMAUD, Amaury Patrick; VASCONCELLOS, Marco Antonio Sandoval de; TONETO JR. Rudinei. Economia Brasileira Contemporânea. $7^{a}$ ed. São Paulo, SP: Atlas, 2007, p. 322. ${ }^{3}$ GREMAUD, Amaury Patrick; VASCONCELLOS, Marco Antonio Sandoval de; TONETO JR. Rudinei. Economia Brasileira Contemporânea. $7^{a}$ ed. São Paulo, SP: Atlas, 2007. 
fenômeno respaldava, ao final do regime militar, o diagnóstico de que a inflação brasileira não estava relacionada com a atividade econômica.

Desde a década de 1970 até março de 1985, a inflação apresentou dois movimentos. Um primeiro ocorrido em 1979, no qual, com o segundo choque do petróleo, a política interna de "fixação realista" e o simultâneo aumento da frequência dos reajustes salariais de anual para semestral dobraram, a inflação, que passou à taxa de $100 \%$ anual. E o segundo, em 1983, impulsionado por uma maxidesvalorização de $30 \%$ do cruzeiro em fevereiro, no qual a inflação novamente dobrara, atingindo a taxa de $200 \%$ anual. ${ }^{4}$

Macarini ${ }^{5}$ argumenta que, no decurso de 1983, entramos em uma situação de moratória de facto - foram sete cartas de intenções enviadas ao FMI (Fundo Monetário Internacional), de acordo com Carneiro e Modiano $^{6}$ - e que o Brasil enfrentava sua maior crise econômica desde o início da industrialização, na década de 1930. Outrossim, "os planos de estabilização de inspiração ortodoxa, adotados no período de 1981-84, promoveram o ajustamento externo da economia, mas não conseguiram evitar a escalada da inflação". ${ }^{7}$ Este fato fez com que ideias baseadas no caráter inercial da inflação aparecessem e se firmassem. ${ }^{8}$

Utilizamos o aporte da teoria neo-estruturalista da inflação inercial, para considerar a existência de duas causas fundamentais da inflação brasileira: a crise fiscal e a inércia inflacionária. É uma perspectiva que distingue os fatores aceleradores dos fatores mantenedores da inflação.

${ }^{4}$ Cf. MODIANO, Eduardo. A ópera dos três Cruzados: 1985-1989. In: Marcelo de Paiva Abreu (Org.). A Ordem do Progresso: cem anos de política econômica republicana: 1889-1989. Rio de Janeiro, RJ: Editora Campus, 1990.

${ }^{5}$ Cf. MACARINI, José Pedro. A Política econômica do Governo Sarney: os Planos Cruzado (1986) e Bresser (1987). Textos para Discussão, IE/UNICAMP, No. 157, 2009.

${ }^{6}$ Cf. CARNEIRO, Dionísio Dias; MODIANO, Eduardo. Ajuste externo e desequilíbrio interno: 1980-1984. In. Marcelo de Paiva Abreu (Org.). A Ordem do Progresso: cem anos de política econômica republicana: 1889-1989. Rio de Janeiro, RJ: Editora Campus, 1990.

${ }^{7}$ MODIANO, Eduardo. A ópera dos três Cruzados: 1985-1989. In: Marcelo de Paiva Abreu (Org.). A Ordem do Progresso: cem anos de política econômica republicana: 1889-1989. Rio de Janeiro, RJ: Editora Campus, 1990, p. 347.

${ }^{8}$ Cf. CARNEIRO, Dionísio Dias; MODIANO, Eduardo. Ajuste externo e desequilíbrio interno: 1980-1984. In. Marcelo de Paiva Abreu (Org.). A Ordem do Progresso: cem anos de política econômica republicana: 1889-1989. Rio de Janeiro, RJ: Editora Campus, 1990. 
Segundo Bresser-Pereira9 ${ }^{9}$ é uma perspectiva que se distingue das teorias monetaristas, baseadas no déficit público, na emissão de moeda e nas decorrentes expectativas inflacionárias, bem como das teorias keynesianas apoiadas no déficit público e no decorrente excesso de demanda, que não explicavam a inflação brasileira, resultando em medidas insuficientes para o controle da inflação a longo prazo.

A inflação brasileira era também uma inflação para a qual as políticas de estabilização ortodoxas ou convencionais, de caráter monetarista e keynesiano, baseadas no ajuste fiscal e no controle monetário, não se mostravam efetivas, na medida em que a inércia inflacionária tornava a oferta de moeda passiva.

A teoria neo-estruturalista da inflação inercial surge do diagnóstico inercial da inflação, que tornou-se a principal abordagem na década de 1980, contudo, derivando em duas vertentes da inflação inercial, que gerariam dois modos distintos de enfrentar a inflação: uma visão mais ortodoxa, do tratamento de choque, que previa o congelamento de preços, com um choque drástico na inflação; e uma visão mais heterodoxa, do gradualismo, que previa a indexação total da economia como estratégia de coordenação prévia dos aumentos de preços, acompanhada por uma reforma monetária na qual se procedia à desindexação. Haveria a coexistência transitória da moeda velha com a nova, que seria indexada ao índice de inflação e tornada constante em relação a uma base de liquidez monetária, o dólar. O pressuposto é o de que a nova moeda tenderia a rapidamente expulsar a antiga. ${ }^{10}$

Assim, busca-se evitar congelamentos e empreender a indexação total da economia. Com um diagnóstico e ações com efeitos menos drásticos que no diagnóstico de choques, era imprescindível a necessidade de apoio político, significando o apoio para o ajuste fiscal e para um acordo social, pois seus resultados não apareceriam na mesma intensidade que no diagnóstico de choques.

Para que a teoria neo-estruturalista da inflação inercial funcione, necessita de uma liderança política que logre o apoio político necessário para a indexação total, e o gradual controle inflacionário, bem como a reforma fiscal que possibilitaria a manutenção do controle inflacionário.

Concomitantemente aos debates econômicos para solucionar a problemática inflacionária, no âmbito político, a Nova República emerge em um panorama conturbado, no qual as eleições realizadas no Colégio

${ }^{9}$ BRESSER PEREIRA, Luiz Carlos. A Economia e a Política do Plano Real. Revista de Economia Política, Vol. 14, 4, 1994, p. 129-130.

${ }^{10}$ BRESSER PEREIRA, Luiz Carlos. A Economia e a Política do Plano Real. Revista de Economia Política, Vol. 14, 4, 1994, p. 130-132.

2 JOURNAL OF INSTITUTIONAL STUDIES 1 (2016) 
Eleitoral, em janeiro de 1985, após quase 21 anos de governos militares, elegem a aliança opositora (Aliança Democrática), conformada por Tancredo Neves (Partido do Movimento Democrático Brasileiro - PMDB) e José Sarney (Frente Liberal). Buscando manter a confiança dos setores apoiadores à Aliança Democrática, o resultado foi a definição de um quadro de ministros marcado pela heterogeneidade. ${ }^{11}$ Com isso, a transição articulada pelo PMDB e pela Frente Liberal (dissidência do governista Partido Democrático Social) sinalizava para o desenvolvimento de um processo dual "integrando mudanças (nova Constituição, eleições diretas generalizadas) e continuidade (tudo indica, no campo da política econômica)" ${ }^{12}$

Todavia, o cenário se altera drasticamente quando Tancredo Neves adoece as vésperas da posse, ocorrida em 15 de março de 1985. Em seu lugar, assume o vice José Sarney, que, logo após o falecimento de Neves (em 21 de abril), é confirmado no cargo. Neste interim, acirraram-se os debates acerca da legitimidade da transferência do $\operatorname{cargo}^{13}$, já que Tancredo não havia assumido oficialmente, e os militares da linha dura não estavam totalmente convencidos da necessidade da transição para a democracia. Assim, Sarney assume a presidência devendo manter as alianças e nomeações formalizadas por Tancredo, em um ambiente de profunda desconfiança, inclusive no interior do PMDB. ${ }^{14}$

Nesse ponto, chegamos a nosso objeto de análise. A partir do governo José Sarney até Fernando Henrique Cardoso, com o Plano Real, uma "saga de planos heterodoxos" (segundo Gremaud, Vasconcellos e Toneto Jr. ${ }^{15}$ ) é traçada -, e, neste trabalho, procura-se apontar seus principais desenlaces, seguindo uma linha de raciocínio paralela aos movimentos

${ }^{11}$ Cf. GREMAUD, Amaury Patrick; VASCONCELLOS, Marco Antonio Sandoval de; TONETO JR. Rudinei. Economia Brasileira Contemporânea. $7^{a}$ ed. São Paulo, SP: Atlas, 2007; e AMES, Barry. Os entraves da democracia no Brasil. Rio de Janeiro, RJ: Editora FGV, 2003.

${ }^{12}$ MACARINI, José Pedro. A Política econômica do Governo Sarney: os Planos Cruzado (1986) e Bresser (1987). Textos para Discussão, IE/UNICAMP, No. 157, 2009, p. 11.

${ }^{13} \mathrm{O}$ presidente Figueiredo, por exemplo, não compareceu à cerimônia de transferência do cargo à Sarney.

${ }^{14}$ Cf. MACARINI, José Pedro. A Política econômica do Governo Sarney: os Planos Cruzado (1986) e Bresser (1987). Textos para Discussão, IE/UNICAMP, No. 157, 2009. ${ }_{15}$ GREMAUD, Amaury Patrick; VASCONCELLOS, Marco Antonio Sandoval de; TONETO JR. Rudinei. Economia Brasileira Contemporânea. $7^{a}$ ed. São Paulo, SP: Atlas, 2007. 
cíclicos econômicos de ascensão e queda das medidas adotadas por cada planejamento governamental anti-inflacionário.

Dividido em três momentos, o trabalho busca examinar o contexto político-institucional, a descrição dos planos econômicos, os empecilhos e ensejos à exequibilidade das medidas anti-inflacionárias atribuídas pelas relações políticas intensificadas com a redemocratização e os êxitos e fracassos dessa saga no combate à hiperinflação. Em ordem cronológica são apresentados estes fatores durante os governos de José Sarney, Fernando Collor de Mello, Itamar Franco e Fernando Henrique Cardoso.

Para tanto, se lançará mão de uma revisão bibliográfica que aprecie a influência das relações políticas para a formulação e execução das políticas de estabilização econômica, apresentando e analisando o modo como os compromissos políticos dos governos, em um cenário de transição política permeado de incertezas, ademais das relações entre os poderes estabelecidas pela institucionalidade proveniente da Constituição de 1988, forneceram desafios adicionais para a resolução da problemática da hiperinflação.

\section{A INTERAÇÃO DE FATORES POLÍTICOS E ECONÔMICOS NOS PLANOS DE ESTABILIZAÇÃO}

\section{Governo Sarney: a busca por apoio popular e parlamentar}

No afã de compreendermos o comportamento do governo Sarney no concernente aos compromissos políticos que influenciaram os planos de estabilização, faz-se necessário considerarmos uma diferença fundamental entre ele e Tancredo. Realizando uma apreciação geral de ambos os líderes políticos, Macarini ${ }^{16}$ afirma que Sarney, por um lado, incorporou à sua proposta de governo, tanto setores da direita, quanto da esquerda. Sarney não queria oposição, formando um projeto de mais longo alcance. Tancredo, por outro lado, queria oposição contra ele, e queria derrotá-la.

O Governo Sarney não era o esperado dentro do processo de redemocratização. Havia uma expectativa por um governo democrático, via eleições diretas, que foi rejeitada com a emenda Dante de Oliveira (1984). José Sarney, político historicamente ligado à ARENA/PDS, era vice de Tancredo Neves, e representou um governo fora do esperado

${ }_{16}$ MACARINI, José Pedro. A Política econômica do Governo Sarney: os Planos Cruzado (1986) e Bresser (1987). Textos para Discussão, IE/UNICAMP, No. 157, 2009.

2 JOURNAL OF INSTITUTIONAL STUDIES 1 (2016) 
dentro de um cenário econômico com crescentes complicações.

A análise de Macarini ${ }^{17}$ nos mostra como Sarney era visto politicamente. De fato, investido acidentalmente como presidente, ele não tinha nenhum compromisso com a orientação política do Banco Central de manter "uma política monetária firmemente ativa". Sarney havia conformado a Aliança Democrática representando a Frente Liberal e, ao assumir o poder, muda sua afiliação partidária para o PMDB. Contudo, sendo personagem intruso neste partido e de base de apoio político frágil, era inevitável a atmosfera de desacordo profundo no interior do governo. ${ }^{18}$

Nesse sentido, as nomeações ministeriais tornam-se um elemento fundamental para angariar apoio, principalmente quando o Executivo enfrenta desconfiança generalizada. Isto pois "as nomeações para o ministério são uma arma fundamental do presidente na busca de apoio parlamentar. Todo presidente calcula quantos votos legislativos os ministros podem atrair em seus partidos e estados" ${ }^{19}$ No que tange à área econômica, a nomeação dos principais ministros, provenientes do Rio de Janeiro e São Paulo, "tinha por objetivo muito mais tranquilizar os industriais do que prover benefícios particularistas" ${ }^{20}$

O governo Sarney começou a luta contra a inflação com um plano heterodoxo, o Plano Cruzado. De acordo com Modiano, tal plano mostrou resultados que podem ser divididos em três períodos:

O primeiro período, que vai de março a junho de 1986, é caracterizado por uma queda substancial da inflação e também pelos primeiros indícios da existência de excesso de demanda na economia. O segundo período, que vai de julho a outubro de 1986, pode ser identificado pela total imobilidade do governo ante o agravamento da escassez de produtos e à deterioração das contas externas. Finalmente, o terceiro período, que vai de

${ }^{17}$ MACARINI, José Pedro. A Política econômica do Governo Sarney: os Planos

Cruzado (1986) e Bresser (1987). Textos para Discussão, IE/UNICAMP, No. 157, 2009.

${ }^{18}$ MACARINI, José Pedro. A Política econômica do Governo Sarney: os Planos

Cruzado (1986) e Bresser (1987). Textos para Discussão, IE/UNICAMP, No. 157, 2009,

p. 15.

${ }^{19}$ AMES, Barry. Os entraves da democracia no Brasil. Rio de Janeiro, RJ: Editora FGV, 2003, p. 206.

${ }_{20}$ AMES, Barry. Os entraves da democracia no Brasil. Rio de Janeiro, RJ: Editora FGV, 2003, p. 208. 
novembro de 1986 a junho de 1987, ratificou o fracasso do Plano Cruzado, com o retorno das altas taxas de inflação. ${ }^{21}$

O Plano Cruzado, além de introduzir uma nova moeda (o cruzado), contemplava, entre outras questões, o congelamento geral dos preços, gatilho salarial, taxa de câmbio fixada, os aluguéis tiveram valores médios recompostos por meio de fatores multiplicativos, e para os ativos financeiros foram criadas diferentes regras - dentre elas, a introdução da Tablita para contratos prefixados..$^{22}$

Com vistas a aumentar sua aceitação interna no PMDB, bem como gerar maior legitimidade ao seu governo, Sarney buscou, no apoio popular, a base para a sustentação de seu governo e do Plano Cruzado. Isto pode ser observado quando encontra-se entre as medidas do plano um abono salarial de $8 \%$, e de $16 \%$ para o salário mínimo. "Esse abono era eminentemente político e visava transferir renda aos assalariados" ${ }^{23}$ O grande problema que emerge, nesse contexto, é o efeito inflacionário do abono salarial, já que, com o congelamento de preços, o abono representava um ganho real de poder de consumo para os assalariados, o que poderia pressionar a demanda e resultar em nova aceleração inflacionária.

É preciso ressaltar que o congelamento "experimentado pela primeira vez após um longo período de convivência com a inflação alta, foi entusiasticamente apoiado pela maioria da população (que durante algum tempo, vestiu a camiseta de 'fiscal do presidente')". ${ }^{24}$ De fato, "o congelamento de preços do Plano Cruzado tornara-se a base da popularidade do governo". ${ }^{25}$

O atrelamento do governo ao congelamento era de tal forma que,

${ }^{21}$ MODIANO, Eduardo. A ópera dos três Cruzados: 1985-1989. In: Marcelo de Paiva Abreu (Org.). A Ordem do Progresso: cem anos de política econômica republicana: 1889-1989. Rio de Janeiro, RJ: Editora Campus, 1990, p. 360.

${ }^{22}$ Cf. GREMAUD, Amaury Patrick; VASCONCELLOS, Marco Antonio Sandoval de; TONETO JR. Rudinei. Economia Brasileira Contemporânea. $7^{a ̊ a}$ ed. São Paulo, SP:

Atlas, 2007.

${ }^{23}$ Cf. GREMAUD, Amaury Patrick; VASCONCELLOS, Marco Antonio Sandoval de; TONETO JR. Rudinei. Economia Brasileira Contemporânea. $7^{a}$ ed. São Paulo, SP:

Atlas, 2007, p. 423.

${ }^{24}$ MACARINI, José Pedro. A Política econômica do Governo Sarney: os Planos

Cruzado (1986) e Bresser (1987). Textos para Discussão, IE/UNICAMP, No. 157, 2009, p. 27.

${ }^{25}$ BAER, Werner. A Economia Brasileira. São Paulo, SP: Nobel, 1996, p. 172. 
mesmo com os problemas que o plano mostrava - o excesso de demanda e a escassez de produtos -, o governo recorreu a mecanismos alternativos ao descongelamento para contornar a situação. Tal postura, por sua vez, resultou no aparecimento de ágios, maquilagem de produtos, mudança na embalagem, forçando o governo a escolher entre desacelerar a economia ou romper com o congelamento - o qual "foi tornando-se inócuo e as tentativas de mantê-lo acabavam rebatendo no lado fiscal e nas contas externas do país"26; resultado: o "Cruzadinho".

Enquanto pacote fiscal elaborado para desaquecer o consumo, o Cruzadinho envolvia "um sistema de empréstimos compulsórios. [...] A receita adicional do governo financiaria o Plano de Metas, um programa de investimentos públicos e privados anunciado simultaneamente, que visava um crescimento anual do PIB de $7 \% "{ }^{27}$

Todavia, a política econômica ficou paralisada, pois a atenção do governo focava-se nas eleições gerais de novembro de 1986 para governadores e para a Assembleia Constituinte. Do mesmo modo, o fim do Cruzado levou a uma expectativa de descongelamento que induziria o aumento do consumo - contrariando os objetivos do Cruzadinho.

Não obstante os desequilíbrios econômicos crescentes advindos do Plano Cruzado, o governo Sarney logrou capitalizar os benefícios políticos do congelamento de preços atrelado ao abono salarial, convertendo-os em votos para o PMDB nas eleições de novembro. Como resultado desse quadro, o PMDB elegeu 22 dos 23 governadores (a outra legenda que elegeu um governador foi o PFL - Partido da Frente Liberal), 38 dos 49 senadores (77,55\%) e 261 dos 487 deputados federais (53,59\%), representando uma grande vitória política da ala governista. ${ }^{28}$

Assim, "uma semana após a vitória maciça do partido do governo (PMDB) nas eleições, o [Plano] Cruzado II foi anunciado" ${ }^{29}$, contando

${ }^{26}$ Cf. GREMAUD, Amaury Patrick; VASCONCELLOS, Marco Antonio Sandoval de; TONETO JR. Rudinei. Economia Brasileira Contemporânea. $7^{a}$ ed. São Paulo, SP:

Atlas, 2007, p. 440.

${ }^{27}$ MODIANO, Eduardo. A ópera dos três Cruzados: 1985-1989. In: Marcelo de Paiva Abreu (Org.). A Ordem do Progresso: cem anos de política econômica republicana: 1889-1989. Rio de Janeiro, RJ: Editora Campus, 1990, p. 363.

${ }^{28}$ Cf. MAINWARING, Scott. Brasil: partidos débiles, democracia indolente. In: Scott Mainwaring; Timothy Scully (eds.). La construcción de instituciones democráticas: sistemas de partidos en América Latina. Santiago: CIEPLAN, 1996.

${ }^{29}$ MODIANO, Eduardo. A ópera dos três Cruzados: 1985-1989. In: Marcelo de Paiva Abreu (Org.). A Ordem do Progresso: cem anos de política econômica republicana: 1889-1989. Rio de Janeiro, RJ: Editora Campus, 1990, p. 363. 
com o respaldo das urnas. E, desta vez, o que se objetivava era "controlar o déficit público pelo aumento da receita em $4 \%$ do PIB, com base no aumento de tarifas e impostos indiretos. Foi uma tentativa de alinhar alguns preços, principalmente dos bens de consumo da classe média". ${ }^{30}$

Destarte, o Plano Cruzado II gerou um violento choque inflacionário, o que significaria o retorno descomedido da indexação da economia com o reajuste mensal dos salários a economia acabou se tornando mais indexada do que antes do Plano Cruzado. ${ }^{31} \mathrm{O}$ governo colocara em marcha uma política monetária restritiva, paralelamente com esse pacote. Assim, a volta da inflação, dentro desse cenário conformado por mecanismos de indexação formais eliminados e por política de restrição de crédito -, provocou uma grande instabilidade financeira. ${ }^{32}$

No início de 1987 o governo reintroduziu uma indexação parcial e "para salvar alguns setores endividados, recorreu a uma série de pacotes de ajuda que contribuíram para piorar ainda mais a situação fiscal". ${ }^{33} \mathrm{O}$ quadro deteriorou-se com a evasão de reservas que forçou o governo a declarar moratória.

A moratória per se tinha dois objetivos, o oficial e o extraoficial. $\mathrm{O}$ primeiro era "estancar a perda de reservas cambiais e iniciar uma nova fase nas negociações da dívida externa", enquanto o segundo "seria a reconquista do apoio popular, prejudicado pelo fracasso do Plano Cruzado para uma nova tentativa de estabilização". ${ }^{34}$

Em abril do mesmo ano, a taxa de inflação ultrapassou o patamar de $20 \%$ ao mês, e o ministro Dílson Funaro deixaria o cargo, sem a realização de seus anseios do fim da "bolha inflacionária" e a renegociação da dívida

${ }^{30}$ Cf. GREMAUD, Amaury Patrick; VASCONCELLOS, Marco Antonio Sandoval de; TONETO JR. Rudinei. Economia Brasileira Contemporânea. $7^{a}$ ed. São Paulo, SP: Atlas, 2007, p. 441.

${ }^{31}$ Cf. MODIANO, Eduardo. A ópera dos três Cruzados: 1985-1989. In: Marcelo de Paiva Abreu (Org.). A Ordem do Progresso: cem anos de política econômica republicana: 1889-1989. Rio de Janeiro, RJ: Editora Campus, 1990.

${ }_{32}$ Cf. GREMAUD, Amaury Patrick; VASCONCELLOS, Marco Antonio Sandoval de; TONETO JR. Rudinei. Economia Brasileira Contemporânea. $7^{a}$ ed. São Paulo, SP: Atlas, 2007.

${ }^{33}$ GREMAUD, Amaury Patrick; VASCONCELLOS, Marco Antonio Sandoval de; TONETO JR. Rudinei. Economia Brasileira Contemporânea. $7^{a}$ ed. São Paulo, SP: Atlas, 2007, p. 442. ${ }^{34}$ MODIANO, Eduardo. A ópera dos três Cruzados: 1985-1989. In: Marcelo de Paiva Abreu (Org.). A Ordem do Progresso: cem anos de política econômica republicana: 1889-1989. Rio de Janeiro, RJ: Editora Campus, 1990, p. 365. 
externa ${ }^{35}$ No entanto, para Bresser-Pereira, a moratória, assim como o Plano Cruzado II, resultou em um "fiasco quase instantâneo". Isto ocorreu pois ambos não desfrutaram de apoio junto aos setores populares, ademais de impacientar os setores conservadores. Porém, um fator fundamental para tal panorama foi o prosseguimento do governo Sarney por uma "rota vacilante", representando um "reflexo do jogo político em que estava engajado, de forma que, tomada a decisão, não demorou para que surgissem os sinais de recuo em face dos desdobramentos que fugiam ao desejado". ${ }^{36}$

Com uma conjuntura econômica em profunda tensão "esfacelamento da equipe econômica responsável pelo Plano Cruzado, a posição de extrema fragilidade vivida pelo ministro Funaro, o estado de indefinição do governo Sarney, a progressiva deterioração da economia"37 - Luiz Carlos Bresser-Pereira elabora um plano de emergência que pretendia imprimir um misto de racionalidade $\mathrm{e}$ soberania à condução da política econômica, e que se diferenciava principalmente em dois pontos do plano anterior: a estratégia fundamental pauta-se na reforma tributária e uma política monetária mais flexível.

As principais medidas do Plano Bresser foram: congelamento dos salários e preços por três meses; mudança da base do Índice de Preços ao Consumidor (IPC); desvalorização cambial e não congelamento da taxa de câmbio; aluguéis congelados no nível de junho; contratos financeiros pós-fixados mantidos e prefixados com uma Tablita, com desvalorização de $15 \%$ mensal; e a criação da Unidade Referencial de Preços (URP). Mesclavam-se elementos ortodoxos com heterodoxos. ${ }^{38}$

Quanto ao seu desenlace, Modiano divide o plano em dois períodos:

${ }^{35}$ Cf. MODIANO, Eduardo. A ópera dos três Cruzados: 1985-1989. In: Marcelo de Paiva Abreu (Org.). A Ordem do Progresso: cem anos de política econômica republicana: 1889-1989. Rio de Janeiro, RJ: Editora Campus, 1990.

36 BRESSER-PEREIRA, Luiz Carlos apud MACARINI, José Pedro. A Política econômica do Governo Sarney: os Planos Cruzado (1986) e Bresser (1987). Textos para Discussão, IE/UNICAMP, No. 157, 2009, p. 37-38.

${ }^{37}$ MACARINI, José Pedro. A Política econômica do Governo Sarney: os Planos Cruzado (1986) e Bresser (1987). Textos para Discussão, IE/UNICAMP, No. 157, 2009, p. 43.

${ }^{38}$ Cf. GREMAUD, Amaury Patrick; VASCONCELLOS, Marco Antonio Sandoval de; TONETO JR. Rudinei. Economia Brasileira Contemporânea. $7^{a \mathfrak{a}}$ ed. São Paulo, SP: Atlas, 2007. 
O primeiro período, que vai de julho a dezembro de 1987, inclui as fases de congelamento e flexibilização do Plano Bresser, configurando o sucesso inicial e o fracasso posterior desta segunda tentativa. O segundo período, que vai de janeiro a dezembro de 1988, é caracterizado por um renascimento da ortodoxia e por uma retomada do gradualismo no combate à inflação. No final de 1988 a economia parecia novamente se encontrar no limiar da hiperinflação. ${ }^{39}$

Para se compreender a intensificação do processo hiperinflacionário, deve-se ter em conta que 1988 representou um momento político crucial para a Nova República. Este era o ano em que seria promulgada a nova Constituição, e dois pontos forçosos para Sarney eram a manutenção do presidencialismo e a prorrogação de seu mandato para cinco anos. "Durante a crise institucional de 1988, Sarney precisou usar de todos os expedientes políticos". Sarney alterou as táticas empregadas previamente, primeiramente de favorecer os peemedebistas, e posteriormente uma conjugação do apoio ao PFL com a manutenção do apoio dos deputados eleitoralmente dominantes do PMDB, passando à tática de favorecer quem se dispusesse a apoiá-lo. Além disso, ofereceu benefícios aos municípios fragmentados, inclusive os controlados pelo PMDB ou PFL. "Nesses lugares, somente governos em situação desesperadora iriam se aventurar, e Sarney deve ter encontrado quem se dispusesse a competir pelas sobras que lhes destinou". ${ }^{40}$

Como Gremaud, Vasconcellos e Toneto Jr. ${ }^{41}$ apontam, o Plano falhou na contenção do déficit público, que se elevou em $1987^{42}$, em parte, devido à prioridade de Sarney em lograr uma votação favorável na Constituinte, ou seja, com o direcionamento de recursos ao aumento do funcionalismo

${ }^{39}$ MODIANO, Eduardo. A ópera dos três Cruzados: 1985-1989. In: Marcelo de Paiva Abreu (Org.). A Ordem do Progresso: cem anos de política econômica republicana: 1889-1989. Rio de Janeiro, RJ: Editora Campus, 1990, p. 368.

${ }^{40}$ AMES, Barry. Os entraves da democracia no Brasil. Rio de Janeiro, RJ: Editora FGV, 2003, p. 223.

${ }^{41}$ Cf. GREMAUD, Amaury Patrick; VASCONCELLOS, Marco Antonio Sandoval de; TONETO JR. Rudinei. Economia Brasileira Contemporânea. $7^{a}$ ed. São Paulo, SP: Atlas, 2007.

42 A Nova República iniciou com uma relação déficit público/PIB de 4,3\% em 1985, reduzindo a mesma para 3,6\% em 1986, contudo, retomando o movimento ascendente em 1987, com 5,5\%. Cf. BRESSER-PEREIRA, Luiz Carlos. Os dois congelamentos de preços no Brasil. Revista de Economia Política, Vol. 8, ํo. . 4, 1988. 
e aumento das transferências a Estados e Municípios, juntamente com os subsídios às empresas estatais - o que dificultava a austeridade fiscal. Assim, de certa forma frustrado com a "falta de prosseguimento" de seu Plano, e com a economia em "balburdia", Bresser-Pereira pediu demissão em dezembro de 1987 e assumiu o Ministro Mailson da Nóbrega. ${ }^{43}$

Ao iniciar sua gestão, o ministro rejeitou a alternativa do choque heterodoxo e pautou a política econômica em dois objetivos: estabilização da inflação em $15 \%$ ao mês e redução gradual do déficit público, projetado em 7 a $8 \%$ do PIB para 1988 - aspectos fundamentais do que ficou conhecido como política do "feijão com arroz". ${ }^{44}$ Para atingir esses objetivos, adotou-se o "congelamento de empréstimos ao setor público, a contenção salarial e a redução no prazo de recolhimento dos impostos. Em 3-1-88, suspendeu a moratória, que havia sido decretada em fevereiro de 1987". ${ }^{45}$

Como resultado dessa política, a inflação havia ficado abaixo de $20 \%$ mensal no primeiro semestre, mas, já no segundo, voltou a aumentar, por consequência da recomposição das tarifas públicas. Um dos fatos que auxiliou esse desenlace foi a promulgação da Constituição de 1988, por ter comprometido $92 \%$ da receita com a transferência a pessoal, encargos, Municípios, Estados e outras vinculações, dificultando um ajuste fiscal proposto nos moldes do programa estabilizador, embora, do ponto de vista político, ela tenha apresentado resultados relativamente distintos. ${ }^{46}$ A Constituição de 1988 representou, para a transição democrática brasileira, um momento fundamental na definição da nova institucionalidade, tanto na dimensão "constitucional" - sistemas eleitoral, partidário e de governo - quanto na "procedimental" - "as

${ }^{43}$ Cf. MACARINI, José Pedro. A Política econômica do Governo Sarney: os Planos Cruzado (1986) e Bresser (1987). Textos para Discussão, IE/UNICAMP, No. 157, 2009;

e GREMAUD, Amaury Patrick; VASCONCELLOS, Marco Antonio Sandoval de; TONETO JR. Rudinei. Economia Brasileira Contemporânea. $7^{a}$ ed. São Paulo, SP:

Atlas, 2007.

${ }^{44}$ MODIANO, Eduardo. A ópera dos três Cruzados: 1985-1989. In: Marcelo de Paiva Abreu (Org.). A Ordem do Progresso: cem anos de política econômica republicana: 1889-1989. Rio de Janeiro, RJ: Editora Campus, 1990.

${ }^{45}$ Cf. GREMAUD, Amaury Patrick; VASCONCELLOS, Marco Antonio Sandoval de; TONETO JR. Rudinei. Economia Brasileira Contemporânea. 7ª ed. São Paulo, SP: Atlas, 2007, p. 445.

${ }^{46}$ Cf. MODIANO, Eduardo. A ópera dos três Cruzados: 1985-1989. In: Marcelo de Paiva Abreu (Org.). A Ordem do Progresso: cem anos de política econômica republicana: 1889-1989. Rio de Janeiro, RJ: Editora Campus, 1990. 
regras que regulam o processo decisório, fundamentalmente as relativas aos poderes de agenda e à capacidade de formulação das políticas públicas por parte dos Poderes Executivo e Legislativo". ${ }^{47}$

A Constituição de 1988 "alterou significativamente o equilíbrio entre os poderes [...] concentrando poder no Executivo". De tal modo, o Executivo passou a dispor de "fortes poderes legislativos e de agenda", centralizando o processo decisório, especialmente com a instituição do mecanismo das Medidas Provisórias, contudo, não podendo simplesmente "ignorar" o Legislativo. ${ }^{48}$

Assim, em 14 de janeiro de 1989 um novo plano surgia, o denominado Plano Verão. Este, assim como o anterior, também mesclava pontos ortodoxos com heterodoxos. Do lado ortodoxo visava a contração da demanda agregada a curto prazo, e do lado heterodoxo "constituiu-se num plano de desindexação ainda mais ambicioso que o Plano Cruzado de fevereiro de 1986 ao suspender ou extinguir todos os mecanismos de realimentação da inflação". ${ }^{49}$

Entretanto, devido à conjuntura política do momento - as eleições de 1989, com um grande número de congressistas se candidatando à reeleição, e seu não comprometimento com medidas impopulares houve descontrole fiscal ${ }^{50}$, provocando um descontrole monetário que, aliado ao imobilismo da política econômica e às incertezas do último ano do governo Sarney, aumentou a inflação, e, consequentemente, e, pôs fim

${ }^{47}$ MORAES, Filomeno. A Constituição do Brasil de 1988 e a Reforma Política. Revista Jurídica da Presidência, Vol. 7, 72, 2005, p. 2.

${ }^{48}$ FIGUEIREDO, Argelina Cheibub; LIMONGI, Fernando. Instituições políticas e governabilidade: desempenho do governo e apoio legislativo na democracia brasileira. In: Carlos Ranulfo Melo; Manuel Alcântara Sáez (Orgs.). A Democracia Brasileira: balanço e perspectivas para o Século 21. Belo Horizonte, MG: Editora UFMG, 2007, p. 147.

${ }^{49}$ MODIANO, Eduardo. A ópera dos três Cruzados: 1985-1989. In: Marcelo de Paiva Abreu (Org.). A Ordem do Progresso: cem anos de política econômica republicana: 1889-1989. Rio de Janeiro, RJ: Editora Campus, 1990, p. 375.

${ }^{50}$ A relação déficit público/PIB que era de 4,3\% em 1988, ascendeu à 6,9\% em 1989. Cf. LANZARINI CASA, Carlos Alberto. Dívida Interna, Inflação e Desinflação (19642004): o financiamento do Estado brasileiro sob a perspectiva da vulnerabilidade externa e da preferência pela liquidez do mercado de títulos públicos. Monografia (XIII Prêmio Tesouro Nacional, Tema "Política Fiscal e Dívida Pública", Terceiro Lugar) - Tesouro Nacional, Poder Executivo, Brasília, 2008. 
ao Plano Verão. ${ }^{51}$

Contrariando esta argumentação, ao analisarem as votações das Medidas Provisórias editadas pelo governo, consideradas o núcleo do Plano Verão, Figueiredo e Limongi ${ }^{52}$ observaram um padrão de acordos firmados entre o governo e as lideranças partidárias à última hora. "O plenário referenda esses acordos, que incluem a seleção das emendas a serem consideradas para aprovação, com base no comportamento disciplinado das bancadas, que seguem as orientações de seus líderes".

Desse modo, as negociações que permearam a aprovação das principais medidas do Plano Verão são consideradas como amostras do papel dos líderes partidários "e do uso estratégico de seus direitos regimentais visando a neutralizar os interesses imediatos de membros da bancada". Isto ocorreria pois os líderes possuíam a premissa de firmar acordos em nome das bancadas partidárias que representavam, fazendoos valer em plenário. ${ }^{53}$

Com isso, Figueiredo e Limongi ${ }^{54}$ consideram que a "estrutura partidária esteve longe de se comportar de maneira errática e aleatória". Isto ocorreu, principalmente, pelo fato de o Executivo negociar com as lideranças partidárias, e não com parlamentares individuais ou grupos de parlamentares. Além disso, "os compromissos firmados com as lideranças partidárias foram honrados em plenário. Os partidos e $\mathrm{o}$ Congresso não agiram como veto players". ${ }^{55}$ As tensões foram contornadas, - e o PMDB apenas defendeu pontos de seu programa, bem como os demais partidos, conformando um cenário no qual os "aspectos ideológicos parecem ter sido tão ou mais importantes que os clientelísticos". .56

Entretanto, mesmo com um cenário institucional propício, no último

${ }^{51}$ Cf. GREMAUD, Amaury Patrick; VASCONCELLOS, Marco Antonio Sandoval de; TONETO JR. Rudinei. Economia Brasileira Contemporânea. $7^{a}$ ed. São Paulo, SP:

Atlas, 2007.

${ }^{52}$ FIGUEIREDO, Argelina Cheibub; LIMONGI, Fernando. Executivo e Legislativo na nova ordem constitucional. $2^{\mathrm{a}}$ ed. Rio de Janeiro, RJ: Editora FGV, 2001, p. 163.

${ }^{53}$ FIGUEIREDO, Argelina Cheibub; LIMONGI, Fernando. Executivo e Legislativo na nova ordem constitucional. 2a ed. Rio de Janeiro, RJ: Editora FGV, 2001, p. 166. ${ }^{54}$ FIGUEIREDO, Argelina Cheibub; LIMONGI, Fernando. Executivo e Legislativo na nova ordem constitucional. $2^{\mathrm{a}}$ ed. Rio de Janeiro, RJ: Editora FGV, 2001, p. 173. ${ }^{55}$ FIGUEIREDO, Argelina Cheibub; LIMONGI, Fernando. Executivo e Legislativo na nova ordem constitucional. $2^{\mathrm{a}}$ ed. Rio de Janeiro, RJ: Editora FGV, 2001, p. 173. ${ }^{56}$ FIGUEIREDO, Argelina Cheibub; LIMONGI, Fernando. Executivo e Legislativo na nova ordem constitucional. $2^{a}$ ed. Rio de Janeiro, RJ: Editora FGV, 2001, p. 173. 
mês do governo Sarney, a taxa inflação atingia 80\% mensal. Esse caminho a passos largos para a hiperinflação foi o quadro econômico que esse governo, que traçou uma verdadeira saga de planos de estabilização econômica, deixaria para a próxima gestão presidencial.

\section{Governo Collor: insulamento burocrático e isolacionismo}

O insulamento burocrático foi a tônica do governo Fernando Collor de Mello (1990-1992). O Presidente da República concentrou, no Poder Executivo, todas as principais funções, com a criação da proteção do núcleo técnico do Estado em relação a interferências externas. ${ }^{57}$ Houve, pois, um processo de centralização e racionalização do Estado brasileiro.

O discurso de campanha de Collor relativo à esfera econômica centrava-se no combate à inflação, que deveria ser dado "em um golpe só", bem como na modernização do sistema produtivo, liberalização comercial e diminuição da participação estatal na economia. Em suma, a superação do legado defasado do desenvolvimentismo por meio de um projeto marcadamente de caráter neoliberal.

No entanto, Rodrigues ${ }^{58}$ aponta para a moralidade e o anti-sarneyzismo como os pilares das campanhas de Collor (Partido da Reconstrução Nacional - PRN) e Lula (Partido dos Trabalhadores - PT), marginalizando os problemas econômicos na angariação de votos.

Confirmada a vitória de Collor no pleito $^{59}$, a definição dos ministros do governo passou a ser enfocada. No concernente à pasta da Fazenda, a lógica da gestão tecnocrática se manteve, com a nomeação de Zélia Cardoso de Melo, que recebeu plenos poderes do Presidente para a condução de programas que visassem à estabilização econômica, com novo processo de aceleração inflacionária no final do mandato de Sarney, observando-se uma inflação acumulada de 1972,91\% no ano de 1989 (IPCA do IBGE).

57 Cf. NUNES, Edson de Oliveira. A Gramática Política do Brasil: Clientelismo e Insulamento Burocrático. Rio de Janeiro, RJ/Brasília, DF: J. Zahrar Editor/Escola Nacional de Administração Pública, 1997.

${ }_{58}$ Cf. RODRIGUES, Alberto Tosi. O Brasil de Fernando a Fernando: neoliberalismo, corrupção e protesto na política brasileira de 1989 a 1994. Ijuí, RS: Editora UNIJUÍ, 2000. ${ }^{59}$ No segundo turno, Collor obteve $53,03 \%$ dos votos válidos contra $46,97 \%$ de Lula. Cf. ATLAS DAS ELEIÇÕES PRESIDENCIAIS NO BRASIL. Eleição de 1989. 2014. Disponível em: <https://sites.google.com/site/atlaseleicoespresidenciais/1989>. Acesso em: 20 de abril de 2016. 
Ames $^{60}$ define a formação do gabinete do governo Collor como uma estratégia de recrutamento de partidários fiéis. Assim, deu preferência à nomeação de ministros "que não lhe trouxessem problemas políticos e pessoais". Quanto à escolha da ministra da Fazenda, Ames ${ }^{61}$ caracterizaa como "uma economista desconhecida, antiga assessora de primeira hora de Collor".

O insulamento da tomada de decisões econômicas, juntamente com o caráter personalista do governo que, recorrentemente, advogava sua legitimidade conferida nas urnas pelos 35 milhões de votos recebidos, influenciaram a implantação de um novo plano de estabilização já em março de 1990, o Plano Collor I. Segundo Gremaud, Vasconcellos e Toneto Jr.62, o novo plano buscava "romper com a indexação da economia".

Para realizar tal objetivo, as principais medidas adotadas estavam associadas aos planos monetário, fiscal e administrativo. No concernente à reforma monetária, o plano centrava-se na "drástica redução da liquidez da economia, pelo bloqueio de metade dos depósitos a vista, 80\% das aplicações de overnight [de rolagem diária] e fundos de curto prazo e cerca de um terço dos depósitos de poupança. Bloqueou-se em torno de $70 \%$ do $\mathrm{M} 4^{63}$ da economia" ${ }^{64}$, além da conversão do cruzado em cruzeiro.

Quanto à reforma fiscal, buscava-se a promoção de um ajuste fiscal da ordem de $10 \%$ do PIB, por meio da eliminação do déficit projetado de $8 \%$ do PIB, concomitante com o logro de um superávit de $2 \%$. Este ajuste se efetuaria:

por meio da redução do custo de rolagem da dívida pública, suspensão dos subsídios, incentivos fiscais e

${ }^{60}$ AMES, Barry. Os entraves da democracia no Brasil. Rio de Janeiro, RJ: Editora FGV, 2003, p. 210.

${ }^{61}$ AMES, Barry. Os entraves da democracia no Brasil. Rio de Janeiro, RJ: Editora FGV, 2003, p. 210.

${ }^{62}$ GREMAUD, Amaury Patrick; VASCONCELLOS, Marco Antonio Sandoval de; TONETO JR. Rudinei. Economia Brasileira Contemporânea. $7^{a}$ ed. São Paulo, SP: Atlas, 2007, p. 438.

${ }^{63}$ Agregado monetário que constitui a chamada poupança financeira: depósitos de poupança mais títulos públicos de alta liquidez e títulos privados, como depósitos a prazo e letras de câmbio.

${ }^{64}$ GREMAUD, Amaury Patrick; VASCONCELLOS, Marco Antonio Sandoval de; TONETO JR. Rudinei. Economia Brasileira Contemporânea. $7^{a}$ ed. São Paulo, SP: Atlas, 2007, p. 438. 
isenções, ampliação da base tributária pela incorporação dos ganhos da agricultura, do setor externo e dos ganhos de capital nas bolsas. ${ }^{65}$

No que diz respeito à reforma administrativa, iniciaram-se o programa de privatizações, a melhoria de instrumentos para fiscalizar as arrecadações, no afã de reduzir a sonegação e as fraudes, além de medidas para aumentar a eficiência da administração do setor público e reduzir seus gastos, tendo como principal projeto a reforma da estrutura ministerial.

Quanto às medidas monetárias, promoveram-se um novo congelamento de preços e a desindexação de salários em relação à inflação passada; a mudança do regime cambial, que passava a ser flutuante, com as taxas sendo definidas livremente no mercado; e a alteração na política comercial, iniciando o processo de liberalização do comércio exterior, projetando a redução das tarifas de importação de uma média de $40 \%$ para menos de $20 \%$ em quatro anos.

Examinando-se as principais medidas do plano, o confisco da liquidez parece emergir como sua grande âncora. "Buscou-se retomar a capacidade de fazer política monetária ativa congelando o estoque de moeda"66 Contudo, o diagnóstico marcadamente inercial da inflação vivida estimulou a adoção de mais um congelamento geral de preços, observando-se neste um dos principais fatores de limitação do plano. $\mathrm{Na}$ concepção de Bathke "pode-se dizer que os resultados esperados não foram alcançados, em função da pressão para liberação de cruzados, da falta de ajuste fiscal nos Estados e Municípios e do conflito distributivo por causa da recessão" ${ }^{67}$ De tal modo, a inflação acumulada de 1990 foi de 1620,96\% (IPCA do IBGE), representando uma redução em relação ao ano anterior, todavia consistindo em claros indícios de hiperinflação.

No entanto, o Plano Collor I obteve alguns êxitos, destacando-se o default (reestruturação) da dívida pública, com o bloqueio de $75 \%$ dos

${ }^{65}$ GREMAUD, Amaury Patrick; VASCONCELLOS, Marco Antonio Sandoval de; TONETO JR. Rudinei. Economia Brasileira Contemporânea. $7^{a}$ ed. São Paulo, SP: Atlas, 2007, p. 438.

${ }^{66}$ GREMAUD, Amaury Patrick; VASCONCELLOS, Marco Antonio Sandoval de; TONETO JR. Rudinei. Economia Brasileira Contemporânea. 7ª ed. São Paulo, SP: Atlas, 2007, p. 440.

${ }^{67}$ BATHKE, Juliano. Da moeda à inflação: uma análise empírica da economia brasileira a partir de 1980. Monografia (Bacharelado em Ciências Econômicas) Departamento de Ciências Econômicas, Faculdade Estadual de Ciências e Letras de Campo Mourão, Campo Mourão, 2004, p. 53.

2 JOURNAL OF INSTITUTIONAL STUDIES 1 (2016) 
ativos financeiros, a permissão para o Banco Central recomprar títulos que estavam no mercado, e a redução da relação dívida interna/PIB, juntamente com a redução da dívida interna total ${ }^{68}$. Contudo, tais êxitos eram mitigados pelo conflito de resultados entre a política monetária e a política fiscal. ${ }^{69}$

A implantação do plano e de suas principais medidas foi alcançada com a atuação incisiva de Collor, valendo-se do mecanismo das Medidas Provisórias. Tal fenômeno fora possível dada a insegurança devido à "emergência econômica", que poderia dificultar a manutenção da ordem democrática. Para Rodrigues, essa insegurança era "imposta pela escalada inflacionária, que aos olhos de muitos dos atores e analistas brasileiros, no calor da hora, esse perfil político profundamente autoritário do governo Collor minimizava-se" . ${ }^{70}$ Apreciando as reações do Congresso a tal panorama, observa-se que os parlamentares, em várias oportunidades, "entenderam que a rejeição do plano seria o mesmo que mergulhar o país no caos". Com isso, "ao apreciar medidas provisórias, os parlamentares não as comparam com o status quo anterior à sua edição, e sim com a situação que decorreria de sua rejeição".${ }^{71}$ Constituiu-se uma relação de "delegação" em que os parlamentares delegaram a gestão e a direção da economia ao Executivo.

Ademais, era patente que desde sua posse Collor mantinha relações

68 A dívida interna, que representava 21,7\% do PIB em 1989, reduziu-se para 17,8\% em 1990, e teve nova redução em 1991, quando passou a representar 13,9\% do PIB. Cf. LANZARINI CASA, Carlos Alberto. Dívida Interna, Inflação e Desinflação (19642004): o financiamento do Estado brasileiro sob a perspectiva da vulnerabilidade externa e da preferência pela liquidez do mercado de títulos públicos. Monografia (XIII Prêmio Tesouro Nacional, Tema "Política Fiscal e Dívida Pública", Terceiro Lugar) - Tesouro Nacional, Poder Executivo, Brasília, 2008.

${ }^{69}$ A política monetária "contracionista" acabava promovendo o endividamento por meio de despesas com juros reais, enquanto a política fiscal "contracionista" reduzia o déficit público. Cf. LANZARINI CASA, Carlos Alberto. Dívida Interna, Inflação e Desinflação (1964-2004): o financiamento do Estado brasileiro sob a perspectiva da vulnerabilidade externa e da preferência pela liquidez do mercado de títulos públicos. Monografia (XIII Prêmio Tesouro Nacional, Tema "Política Fiscal e Dívida Pública", Terceiro Lugar) - Tesouro Nacional, Poder Executivo, Brasília, 2008.

${ }^{70}$ RODRIGUES, Alberto Tosi. O Brasil de Fernando a Fernando: neoliberalismo, corrupção e protesto na política brasileira de 1989 a 1994. Ijuí, RS: Editora UNIJUÍ, 2000, p. 107.

${ }^{71}$ FIGUEIREDO, Argelina Cheibub; LIMONGI, Fernando. Executivo e Legislativo na nova ordem constitucional. 2ª ed. Rio de Janeiro, RJ: Editora FGV, 2001, p. 158. 
conflituosas com o Congresso, principalmente pelo fato de seu governo não contar com maioria parlamentar. Por conseguinte, a implantação do Plano Collor foi possível após a edição de 29 Medidas Provisórias - 22 delas editadas em seu primeiro dia de mandato, 15 de março de $1990^{72}-$, que constituíam seu plano de estabilização. ${ }^{73}$

A estratégia do governo foi a de forçar o Congresso a aprovar o plano sem modificações, sustentando que qualquer modificação atentaria contra a consistência macroeconômica da proposta. [...] O PMDB, por seu turno, buscou forçar o governo a concessões, contando para tanto com o fato de ser o maior partido no Congresso e deter os votos necessários à aprovação das iniciativas presidenciais. Em sua estratégia de não fazer concessões, o governo recorria também ao veto para tornar letra morta as modificações introduzidas no Plano pelos relatores do PMDB. Em razão desta estratégia, as relações governo-PMDB acabaram marcadas por uma série de quedas-de-braço em que se alternaram vitórias de parte a parte. ${ }^{74}$

Em traços gerais, a contenda entre o governo e o PMDB deu-se em dois pontos fundamentais: o primeiro dizia respeito ao limite de saques nas cadernetas de poupança, em que o PMDB buscava um "relaxamento" desta medida, uma das principais para o controle inflacionário sob a égide do plano; e o segundo referia-se à "regulamentação da faculdade outorgada ao Ministério da Fazenda para autorizar a conversão de cruzados em cruzeiros para atender casos excepcionais", ponto em que o PMDB opunha-se ao poder arbitrário concedido ao governo pela medida. ${ }^{75}$

No concernente ao Plano Collor, “as negociações foram um pouco mais complexas à proporção que as primeiras medidas foram aprovadas

${ }^{72}$ Cf. FIGUEIREDO, Argelina Cheibub; LIMONGI, Fernando. Executivo e Legislativo na nova ordem constitucional. $2^{\mathrm{a}}$ ed. Rio de Janeiro, RJ: Editora FGV, 2001.

${ }^{73}$ Cf. FIGUEIREDO, Argelina Cheibub; LIMONGI, Fernando. O Congresso e as Medidas Provisórias: abdicação ou delegação? Novos Estudos CEBRAP, No. 47, 1997. ${ }^{74}$ FIGUEIREDO, Argelina Cheibub; LIMONGI, Fernando. O Congresso e as Medidas Provisórias: abdicação ou delegação? Novos Estudos CEBRAP, No. 47, 1997, p. 141. ${ }^{75}$ FIGUEIREDO, Argelina Cheibub; LIMONGI, Fernando. Executivo e Legislativo na nova ordem constitucional. $2^{a}$ ed. Rio de Janeiro, RJ: Editora FGV, 2001, p. 184-185. 
em meio a negociações que envolviam o PMDB". ${ }^{76}$ Contudo, na finalização do plano, governo e PMDB desentendem-se e "as últimas medidas a serem votadas o são sem o apoio do PMDB" ${ }^{77} \mathrm{Com}$ tais resultados positivos:

[...] Collor conclui que poderia governar sem o apoio do PMDB, o que o leva a vetar as modificações votadas anteriormente com o apoio daquele partido, e estes vetos não foram derrubados. Ou seja, ainda que o maior partido de oposição oferecesse forte resistência ao governo, não conseguiu reunir maioria capaz de derrubar o veto presidencial. Portanto, se os planos heterodoxos de combate à inflação fracassaram, tal fato não pode ser creditado ao Congresso (grifo nosso). ${ }^{78}$

Considerando-se as votações na Câmara de Deputados, é possível visualizar um cenário geral em que o governo saiu vitorioso, e por larga vantagem, em um "plenário que tendeu a seguir a indicação dos líderes partidários". O mesmo pode ser observado no que tange ao Senado. Ademais, a disciplina partidária vinculava-se a uma certa forma de afiliação ideológica, na qual os partidos de centro-direita votaram com o governo, e os partidos de esquerda votaram contra. Neste sentido, as negociações do governo com o Congresso se davam por meio de interlocutores reconhecidos como tais, os líderes partidários, focando-se mais em interesses partidários (programáticos) que em interesses

${ }^{76}$ FIGUEIREDO, Argelina Cheibub; LIMONGI, Fernando. Instituições políticas e governabilidade: desempenho do governo e apoio legislativo na democracia brasileira. In: Carlos Ranulfo Melo; Manuel Alcântara Sáez (Orgs.). A Democracia Brasileira: balanço e perspectivas para o Século 21. Belo Horizonte, MG: Editora UFMG, 2007, p. 159.

77 FIGUEIREDO, Argelina Cheibub; LIMONGI, Fernando. Instituições políticas e governabilidade: desempenho do governo e apoio legislativo na democracia brasileira. In: Carlos Ranulfo Melo; Manuel Alcântara Sáez (Orgs.). A Democracia Brasileira: balanço e perspectivas para o Século 21. Belo Horizonte, MG: Editora UFMG, 2007, p. 159.

${ }^{78}$ FIGUEIREDO, Argelina Cheibub; LIMONGI, Fernando. Instituições políticas e governabilidade: desempenho do governo e apoio legislativo na democracia brasileira. In: Carlos Ranulfo Melo; Manuel Alcântara Sáez (Orgs.). A Democracia Brasileira: balanço e perspectivas para o Século 21. Belo Horizonte, MG: Editora UFMG, 2007, p. 160 . 
particularistas ou de grupos de parlamentares. ${ }^{79}$

A edição de Medida Provisórias atrelou-se com os planos de estabilização econômica, significando uma ampliação do "âmbito de atuação unilateral do executivo". Porém, "o Congresso, de maneira geral, acatou as MPs emitidas, aprovando a grande maioria delas" ${ }^{80}$ Portanto, considerando-se os custos das políticas de estabilização econômica para os parlamentares, o panorama é das relações Executivo-Legislativo apresentado do seguinte modo:

Estas políticas podem redundar em ganhos generalizados, mas implicam custos certos no presente, sobretudo para grupos específicos. Infligem [...] perdas certas no momento em que são implementadas, sem garantir ganhos no futuro. Por esta razão, parlamentares teriam interesse em delegar função legislativa ao executivo nesta área de política pública, uma vez que não apareceriam como responsáveis diretos por medidas impopulares perante suas constituencies. Por outro lado, se o plano fracassa, os parlamentares não podem ser responsabilizados individualmente. Do ponto de vista institucional, a delegação nessa área de política poderia interessar também, pois, dado que procrastinar eleva os custos do ajuste, o legislativo não apareceria como um empecilho para tomadas de decisões que poderiam beneficiar a todos. ${ }^{81}$

Em síntese, tendo em conta o cenário político-institucional em que conceberam-se os Planos Verão e Collor, "as medidas que compunham o pacote original desses planos foram, em geral, aprovadas com pequenas modificações". Para tanto, os grupos de interesse não vetaram as proposições fundamentais dos planos de estabilização. Foram os líderes partidários que "comandaram negociações políticas cujos acordos foram respaldados por bancadas disciplinadas". ${ }^{82}$

${ }^{79}$ FIGUEIREDO, Argelina Cheibub; LIMONGI, Fernando. Executivo e Legislativo na nova ordem constitucional. $2^{a}$ ed. Rio de Janeiro, RJ: Editora FGV, 2001, p. 176.

${ }^{80}$ FIGUEIREDO, Argelina Cheibub; LIMONGI, Fernando. O Congresso e as Medidas Provisórias: abdicação ou delegação? Novos Estudos CEBRAP, No. 47, 1997, p. 146.

${ }^{81}$ FIGUEIREDO, Argelina Cheibub; LIMONGI, Fernando. O Congresso e as Medidas Provisórias: abdicação ou delegação? Novos Estudos CEBRAP, No. 47, 1997, p. 153. ${ }^{82}$ FIGUEIREDO, Argelina Cheibub; LIMONGI, Fernando. Executivo e Legislativo na nova ordem constitucional. $2^{a}$ ed. Rio de Janeiro, RJ: Editora FGV, 2001, p. 158. 
Com a persistência do quadro de aceleração inflacionária, no início de 1991, juntamente com uma dificuldade crescente de financiamento do governo, com a emissão de títulos públicos, emergiu uma nova tentativa heterodoxa de estabilização monetária, o Plano Collor II.

Esse plano, lançado ainda sob o comando de Zélia Cardoso de Melo, era principalmente uma reforma financeira que visava eliminar o mecanismo de overnight e outras formas de indexação e um congelamento de preços e salários. ${ }^{83}$

Segundo Rodrigues ${ }^{84}$, o novo plano foi recebido com "ceticismo e repúdio", principalmente pelo novo congelamento de preços e pelo fracasso da tentativa anterior. Para Bathke:

com a política de juros elevados, a inflação manteve-se estável, mas não cedeu: de um lado, porque a indexação da economia manteve-se e, de outro, porque as reformas estruturais necessárias para recuperar a política fiscal não foram executadas. ${ }^{85}$

Consequentemente, o plano não alcançou seus objetivos de frear os componentes inerciais da inflação no curto prazo por meio de um choque heterodoxo. Além disso, o surgimento de vários escândalos pessoais e de corrupção dentro do governo - inclusive envolvendo a Ministra da Fazenda-, somado às resistências políticas à equipe econômica, culminou com a substituição de Zélia, em maio de 1991.

A sequência do governo Collor esteve marcada pelos embates crescentes com a oposição e alguns setores da sociedade, relativos a esquemas de corrupção em que o presidente estaria envolvido. $\mathrm{O}$ ano de

${ }^{83}$ GREMAUD, Amaury Patrick; VASCONCELLOS, Marco Antonio Sandoval de; TONETO JR. Rudinei. Economia Brasileira Contemporânea. $7^{a}$ ed. São Paulo, SP: Atlas, 2007, p. 442.

${ }^{84}$ RODRIGUES, Alberto Tosi. O Brasil de Fernando a Fernando: neoliberalismo, corrupção e protesto na política brasileira de 1989 a 1994. Ijuí, RS: Editora UNIJUÍ, 2000.

${ }^{85}$ BATHKE, Juliano. Da moeda à inflação: uma análise empírica da economia brasileira a partir de 1980. Monografia (Bacharelado em Ciências Econômicas) Departamento de Ciências Econômicas, Faculdade Estadual de Ciências e Letras de Campo Mourão, Campo Mourão, 2004, p. 53. 
1992, com a escalada de mobilizações sociais, concomitantemente à abertura de uma Comissão Parlamentar de Inquérito para investigar o tesoureiro da campanha de Collor, Paulo César Farias, fizeram as atenções do governo voltarem-se para a legitimidade política e à busca da governabilidade. À gestão econômica, comandada por Marcílio Marques Moreira, restou uma retomada à ortodoxia, sob a égide do que alguns chamaram de "Plano Nada" ${ }^{86}$ Como resultado, tem-se a retomada da aceleração inflacionária, acumulando $1119,09 \%$ (IPCA do IBGE) no ano, refletindo os efeitos da política de juros elevados juntamente com a manutenção da indexação da economia.

O impeachment do presidente Collor, em outubro de 1992, marcara os traços gerais da política de seu governo, ligados a escândalos de corrupção, personalismo e certo isolacionismo (variando em etapas, aumentando quando lograva vitórias políticas mesmo sem o apoio da oposição), resultando em sua renúncia em 29 de dezembro. Todavia, no tocante ao combate inflacionário, o governo Collor ensaiara a implantação de dois tipos de medidas essenciais para seu êxito, na concepção de Simonsen ${ }^{87}$, que contemplariam tanto fatores monetários e fiscais, quanto o caráter marcadamente inercial da inflação brasileira. Como indício de tais alterações na política econômica, observa-se a mitigação das medidas de corte desenvolvimentista e nacionalista pela ascensão do neoliberalismo brasileiro.

A apreciação adequada dessas medidas contribuiria para o êxito do Plano Real, que reverteu o quadro hiperinflacionário e estabilizou a economia, beneficiando-se especialmente do aumento dos fluxos de capitais internacionais.

\section{Governos Itamar e Cardoso: a estabilização como plataforma eleitoral e governamental}

O Plano Real, que seria até então a décima terceira tentativa de estabilização (como visto na introdução, a primeira fora efetuada em 1979), foi implantado em dezembro de 1993, enquanto Fernando Henrique Cardoso ainda era Ministro da Fazenda, com a finalidade de

${ }^{86}$ Cf. GREMAUD, Amaury Patrick; VASCONCELLOS, Marco Antonio Sandoval de; TONETO JR. Rudinei. Economia Brasileira Contemporânea. $7^{\mathfrak{a}}$ ed. São Paulo, SP:

Atlas, 2007.

${ }^{87}$ SIMONSEN, Mário Henrique. A inflação brasileira: lições e perspectivas. Revista de Economia Política, Vol. 5, 4, 1985, p. 30. 
erradicar a inflação e estabilizar a economia em crise desde antes dos anos 1980. Diferentemente de outros planos, este não contaria com congelamento de preços e salários e seria resultado de uma longa negociação e estudo de caso.

Concebido durante o governo de Itamar Franco (1992-1994), que assumira após a renúncia de Collor, o projeto de estabilização da economia era impulsionado pelo governo após a troca de ministérios efetuada por Fernando Henrique Cardoso, que deixou a pasta das Relações Exteriores para assumir a da Fazenda. "A equipe econômica de Fernando Henrique estava convencida de que qualquer programa de estabilização teria de aplicar um choque fiscal" .88

Para explicar como tais medidas lograram aprovação, mesmo com sua fundamentação no corte de gastos e de repasse de verbas, é preciso considerar-se o quadro político às vésperas das eleições gerais de outubro de 1994, que apontava o favoritismo do candidato do PT, Luiz Inácio Lula da Silva. A direita, encabeçada pelo PFL, não possuía nenhum candidato em condições para vencer Lula. A centro-direita também temia uma vitória de Lula, principalmente quanto às facções mais radicais do PT, que a liderança do PSDB acreditava ser um entrave a seu ímpeto neoliberal do PSDB. Nesse contexto, concebe-se uma aliança entre o PSDB e o PFL para impedir uma possível vitória do PT. ${ }^{89}$

Com o plano em ascensão e atendendo à proposta de estabilização, principalmente no que tange ao controle da inflação, Fernando Henrique beneficiou-se da posição destacada de Ministro da Fazenda no governo Itamar Franco. Com uma coligação entre o PFL e o PSDB, ele reuniu as forças de direita, fazendo frente a seu adversário nas eleições de 1994.

Os líderes pefelistas sabiam que o êxito do plano de estabilização da economia era um pré-requisito para a vitória de Fernando Henrique [...] e achavam que podiam oferecer os votos indispensáveis à aprovação do plano no Congresso. Assim, a liderança da direita tradicional se viu na contingência de respaldar proposições vigorosamente anticlientelistas e antifisiológicas. ${ }^{90}$

88 AMES, Barry. Os entraves da democracia no Brasil. Rio de Janeiro, RJ: Editora FGV, 2003, p. 229-230.

${ }^{89}$ Cf. AMES, Barry. Os entraves da democracia no Brasil. Rio de Janeiro, RJ: Editora FGV, 2003.

${ }^{90}$ AMES, Barry. Os entraves da democracia no Brasil. Rio de Janeiro, RJ: Editora FGV, 2003, p. 231. 
A crise política que pairava sobre as futuras eleições poderia ameaçar a candidatura de Fernando Henrique, como também poderia ser um fator a seu favor. A desarticulação e a ausência de alternativa à política de estabilização monetária por parte das forças políticas relevantes favoreciam a aprovação das medidas, mesmo com o ceticismo generalizado. ${ }^{11}$ Finalmente, com o capital político alcançado pelo Plano Real, Cardoso derrotou Lula já no primeiro turno das eleições, conseguindo $55 \%$ dos votos válidos contra $27 \%$ do candidato petista. ${ }^{92}$

O Plano Real possuía dois pontos fortes: primeiro, um ajuste fiscal, e segundo, um novo sistema de indexação - Unidade Real de Valor (URV) - que levaria à extinção da antiga moeda e originaria uma nova: o Real. O plano era dividido em três fases: a primeira, o ajuste fiscal; a segunda, indexação completa da economia no índice URV; e a terceira, a reforma monetária, ou seja, transformação da URV em reais. ${ }^{93}$

Quanto às políticas de ajuste fiscal, houve um aumento geral de impostos em $5 \%$, sendo que $15 \%$ dos impostos arrecadados iriam para o recém-criado Fundo Social de Emergência (FSE), com a finalidade de se adiantar em relação ao problema de deterioração das contas públicas, ampliando os recursos à disposição do governo federal. Além do FSE, havia o Plano de Ação Imediata (PAI), que determinava um corte de gastos de ordem de US $\$ 7$ bilhões concentrados nas despesas de investimento em pessoal. Já o aumento de arrecadação se daria pela criação do Imposto Provisório sobre Movimentação Financeira (IPMF), era um novo imposto de caráter temporário, sobre movimentações financeiras com alíquota de $0,25 \%$ sobre o valor de toda operação. ${ }^{94}$

Realizadas as medidas da primeira fase, a segunda iniciou-se em fevereiro de 1994, e correspondia ao novo sistema de indexação, que

${ }^{91}$ RODRIGUES, Alberto Tosi. O Brasil de Fernando a Fernando: neoliberalismo, corrupção e protesto na política brasileira de 1989 a 1994. Ijuí, RS: Editora UNIJUÍ, 2000, p. 319.

${ }^{22}$ Cf. TRIBUNAL SUPERIOR ELEITORAL (TSE). Resultados das Eleições de 1994.

2011. Disponível em: $<$ http://www.tse.jus.br/eleicoes/eleicoes-anteriores/eleicoes-

1994/resultados-das-eleicoes-1994/resultados-das-eleicoes-eleicoes-1994>. Acesso em:

20 de abril de 2016.

${ }^{93}$ Cf. FLIGENSPAN, Flávio Benevett. Uma visão global da economia brasileira durante a vigência do Plano Real: avanços impasses e um cenário de crescimento com exclusão. Indicadores Econômicos FEE, Vol. 26, 1, 1998.

${ }_{94}$ Cf. FLIGENSPAN, Flávio Benevett. Uma visão global da economia brasileira durante a vigência do Plano Real: avanços impasses e um cenário de crescimento com exclusão. Indicadores Econômicos FEE, Vol. 26, 1, 1998. 
consistia em indexação diária, substituição parcial da moeda, corrigindo os desequilíbrios dos preços relativos. Nesta fase, foi criada a URV, que tinha seu valor vinculado ao dólar e era reajustada em cruzeiros reais diariamente. O índice URV deveria permanecer o suficiente para "apagar a memória inflacionária da sociedade" e, assim que fosse cumprido esse objetivo, "migrar" a moeda para o Real. Alguns preços e rendimentos foram instantaneamente convertidos em URV: preços oficiais, salários, impostos e contratos. Os outros preços poderiam ser convertidos voluntariamente mais tarde. .5

A URV funcionava como unidade de conta, expressando o preço das mercadorias, porém as transações ainda eram feitas em cruzeiro real, que nesta fase manteve sua função de meio de troca. A função da indexação seria de manter a inflação da moeda em circulação e não na unidade de conta, cujo valor era corrigido pela própria inflação da moeda corrente. ${ }^{96}$

No momento em que todos os preços converteram-se em URV, foi introduzida a nova moeda, o Real, com o valor igual ao da URV e, por consequência, do dólar (em 1ำ de julho de 1994). A política pós-plano consistiria em metas para controlar a demanda e desestimular a especulação, mantendo as taxas de juros elevadas e restringindo operações de crédito. ${ }^{97}$

Quanto à inflação, no período próximo à troca de moeda, segundo Bresser-Pereira ${ }^{98}$, mesmo com a memória inflacionária diluída na URV, toda a conversão de títulos, empréstimos, salários e preços em um curto prazo causou um efeito inflacionário na URV, mas que foi logo compensado com descontos feitos após a conversão total.

A estabilidade de preços foi outro fator responsável pela contenção da inflação. A manutenção de preços estáveis foi produto de um superávit no balanço de pagamentos, permitindo a apreciação cambial do real, aumentando importações e abastecendo suficientemente o mercado

${ }_{95}$ Cf. FLIGENSPAN, Flávio Benevett. Uma visão global da economia brasileira durante a vigência do Plano Real: avanços impasses e um cenário de crescimento com exclusão. Indicadores Econômicos FEE, Vol. 26, 1, 1998.

${ }^{96}$ Cf. FLIGENSPAN, Flávio Benevett. Uma visão global da economia brasileira durante a vigência do Plano Real: avanços impasses e um cenário de crescimento com exclusão. Indicadores Econômicos FEE, Vol. 26, 1, 1998.

${ }^{97}$ Cf. FLIGENSPAN, Flávio Benevett. Uma visão global da economia brasileira durante a vigência do Plano Real: avanços impasses e um cenário de crescimento com exclusão. Indicadores Econômicos FEE, Vol. 26, 1, 1998.

${ }^{98}$ BRESSER PEREIRA, Luiz Carlos. A Economia e a Política do Plano Real. Revista de Economia Política, Vol. 14, 4, 1994, p. 132. 
doméstico, rompendo a possibilidade da propagação de choques (repasse nos preços, tentativas de elevação). Para mitigar desequilíbrios com o fluxo de importações e o déficit na balança comercial, destaca-se a grande quantidade disponível de reservas no exterior, além do fluxo constante de capitais externos devido às altas nas taxas de juros, possibilitando a âncora cambial e forçando a estabilização.

Com a apreciação cambial retirava-se a possibilidade de que os agentes continuem a se comportar como no momento anterior à estabilização, visto que o aumento da capacidade de importação, concedido pela valorização do câmbio e pela manutenção desta, além de canalizar a inflação residual para o câmbio, força os preços a ficarem ancorados aos internacionais..$^{99}$

O primeiro impacto do Plano Real foi a queda da inflação - esta, bem mais lenta que a do Plano Cruzado, em virtude da ausência do congelamento. As taxas de inflação mensais oscilaram consideravelmente, dadas as condições da demanda, porém, sempre com tendência decrescente. Em 1995, a inflação ainda mantinha-se em dois dígitos (14,8\%), mas em 1996 já passaria a ser de um dígito apenas $(9,3 \%)$, chegando a cair para $1,7 \%$ em $1998 .{ }^{100}$

Como o último plano estabilizador, o Plano Real cumpriu a meta principal e o desafio último que não foi possível lograr anteriormente: combater o quadro hiperinflacionário nacional, prescindindo dos choques que marcaram as tentativas anteriores. A estabilização monetária gerou um bom suporte - momentâneo - para a macroeconomia e para a microeconomia, seguindo as diretrizes políticas.

\section{CONCLUSÃO}

Dentro desse contexto, é possível destacar, pois, que a inflação se tornou o problema central da economia e da política brasileiras entre 1985 e 1994, deflagrando uma série de planos econômicos com vistas a sanar tal debilidade que corroía as possibilidades nacionais de institucionalização da democracia recente.

${ }^{99}$ Cf. GREMAUD, Amaury Patrick; VASCONCELLOS, Marco Antonio Sandoval de; TONETO JR. Rudinei. Economia Brasileira Contemporânea. $7^{a}$ ed. São Paulo, SP: Atlas, 2007.

${ }^{100}$ Cf. GREMAUD, Amaury Patrick; VASCONCELLOS, Marco Antonio Sandoval de; TONETO JR. Rudinei. Economia Brasileira Contemporânea. $7^{7 a}$ ed. São Paulo, SP: Atlas, 2007. 
O diagnóstico inequívoco do problema detectava a indexação dos preços como sendo o caráter marcante da inflação brasileira, resultando na abordagem inercialista.

Neste sentido, os planejamentos governamentais para efetivar o controle inflacionário basearam-se em políticas heterodoxas. Com os chamados "choques heterodoxos" da economia, promoveram-se congelamento de preços e salários e desindexação, sem dar a devida atenção aos diagnósticos monetaristas e fiscalistas, que apontavam o déficit público e o déficit externo como problemáticas centrais para a propagação da inflação brasileira. Tais fatores estavam intimamente relacionados com um quadro de recente democratização, a busca pelo apoio político para a realização de uma ampla gama de projetos e a tentativa de converter o endividamento governamental em benefícios políticos. Quando ambos os diagnósticos foram levados em consideração na elaboração do Plano Real, o resultado foi o êxito do combate inflacionário. Contudo, o plano manteve a economia brasileira sacrificando-se para sustentar a estabilidade monetária por quase uma década, sendo esta uma das principais críticas às medidas que ofereceram melhores respostas e resultados ao esforço anti-inflacionário.

Levando em conta os apontamentos de Bresser-Pereira ${ }^{101}$, podemos apreciar o êxito do Plano Real pela conjugação de três fenômenos: a dívida externa não controlada durante os períodos anteriores passou a ser financiada pela chamada "âncora cambial", estabilizando o setor externo superficialmente, por ficar suscetível aos capitais especulativos; o déficit público não controlado fora amenizado pela desestatização da economia; a liderança política conturbada dos governos anteriores marcadamente no governo Sarney, observável na crescente atomização do governo Collor, e na fragilidade do governo Itamar - tornava-os incapazes de estabelecer políticas rígidas de reestruturação econômica que permitissem o ataque tanto inercial quanto monetarista ao problema inflacionário, tendo no governo Cardoso uma abordagem distinta, sendo sua principal plataforma governamental a estabilização da economia brasileira.

Por conseguinte, como apontado por Carvalheiro ${ }^{102}$, a junção dos três fatores na política econômica acarretou na crescente independência do Banco Central, recebendo autonomia gradativa na aplicação das políticas monetária, financeira e cambial, dificultando a possibilidade de

${ }^{101}$ Cf. BRESSER-PEREIRA, Luiz Carlos. Os dois congelamentos de preços no Brasil.

Revista de Economia Política, Vol. 8, no. 4, 1988.

${ }^{102}$ CARVALHEIRO, Nelson. A política monetária no Brasil pós-Real. Pesquisa \&

Debate, Vol. 13, 1, 2002, p. 28.

2 JOURNAL OF INSTITUTIONAL STUDIES 1 (2016) 
"utilização de qualquer forma de atuação governamental".

Portanto, é possível compreender a queda dos planos Cruzado I e II, Bresser, Verão e Collor I e II como motivada pelo processo de identificar corretamente a "doença", entretanto equivocando-se quanto ao "medicamento" eficaz para combatê-la. Tal processo ocorria, em grande medida, pelo terceiro fenômeno elencado por Bresser-Pereira ${ }^{103}$, a liderança política frágil, ávida por legitimidade junto à população, aplicando medidas inflacionárias juntamente com as anti-inflacionárias, como o caso da conjugação de congelamento de preços com o aumento dos salários no Plano Cruzado, pressionando a demanda.

A junção da efetivação de tais práticas permitiu, por consequência, a ascensão do Plano Real como o mais eficaz no combate à inflação, trazendo benefícios políticos para Fernando Henrique Cardoso, culminando com a sua reeleição em 1998, tendo a manutenção do Plano Real como a grande plataforma de campanha. Segundo Gremaud, Vasconcellos e Toneto Jr. ${ }^{104}$, o fato de o plano ser adotado de modo gradativo, sem a utilização de congelamentos, mas com uma "substituição natural" da moeda, valendo-se de uma preocupação com a correção dos desequilíbrios existentes na economia, fez com que o mesmo obtivesse vitórias recorrentes contra a inflação, diferentemente dos choques heterodoxos que obtinham apenas vantagens temporárias, que se convertiam em grandes derrotas em momentos posteriores.

Em última instância, podemos sistematizar a relação entre política e economia nos planos de estabilização desde o Cruzado ao Real do seguinte modo: no governo Sarney, a preocupação com o apoio popular - no primeiro ano de governo -, e parlamentar - fundamentalmente na Constituinte -, fez com que os choques heterodoxos fossem efetuados juntamente com medidas inflacionárias, como o reajuste salarial e o aumento do déficit público, apenas acelerando o quadro inflacionário; no governo Collor, a tentativa de insulamento burocrático da área econômica apenas aumentou a impopularidade das medidas tomadas, e as denúncias de corrupção fizeram com que Collor passasse o ano de 1992 mais preocupado em salvar seu mandato do que em manter o combate à inflação; Itamar ascende ao poder sem grandes perspectivas futuras, mas é com a mudança de Cardoso da pasta de Relações Exteriores para a da Fazenda que a proposta de estabilização econômica ressurge; para evitar

103 Cf. BRESSER-PEREIRA, Luiz Carlos. Os dois congelamentos de preços no Brasil.

Revista de Economia Política, Vol. 8, nº. 4, 1988.

104 GREMAUD, Amaury Patrick; VASCONCELLOS, Marco Antonio Sandoval de; TONETO JR. Rudinei. Economia Brasileira Contemporânea. $7^{a}$ ed. São Paulo, SP: Atlas, 2007.

2 JOURNAL OF INSTITUTIONAL STUDIES 1 (2016) 
uma possível vitória de Lula nas eleições de 1994, o PFL alia-se ao PSDB formando a maioria parlamentar necessária para a aprovação das medidas de estabilização do Plano Real.

É possível, então, depreender que o Plano Real se beneficiou de dois fenômenos conjunturais amplamente favoráveis ao seu êxito: economicamente, o aumento do fluxo de capitais internacionais permitiu a manutenção da âncora cambial, fundamental para o plano; e politicamente, o temor de uma guinada à esquerda, com Lula, trouxe o apoio necessário para a exequibilidade política do plano, favorecendo a aprovação das medidas de estabilização, mesmo quando interferiam no interesse de alguns parlamentares.

\section{REFERÊNCIAS}

AMES, Barry. Os entraves da democracia no Brasil. Rio de Janeiro, RJ: Editora FGV, 2003.

ATLAS DAS ELEIÇÕES PRESIDENCIAIS NO BRASIL. Eleição de 1989. 2014. Disponível em: $<$ https://sites.google.com/site/atlaseleicoespresidenciais/1989>. Acesso em: 20 de abril de 2016.

BAER, Werner. A Economia Brasileira. São Paulo, SP: Nobel, 1996.

BATHKE, Juliano. Da moeda à inflação: uma análise empírica da economia brasileira a partir de 1980. Monografia (Bacharelado em Ciências Econômicas) - Departamento de Ciências Econômicas, Faculdade Estadual de Ciências e Letras de Campo Mourão, Campo Mourão, 2004.

BRESSER PEREIRA, Luiz Carlos. A Economia e a Política do Plano Real. Revista de Economia Política, Vol. 14, 4, 1994. . Os dois congelamentos de preços no Brasil. Revista de

Economia Política, Vol. 8, nº. 4, 1988. 
CARNEIRO, Dionísio Dias; MODIANO, Eduardo. Ajuste externo e desequilíbrio interno: 1980-1984. In. Marcelo de Paiva Abreu (Org.). A Ordem do Progresso: cem anos de política econômica republicana: 1889-1989. Rio de Janeiro, RJ: Editora Campus, 1990.

CARVALHEIRO, Nelson. A política monetária no Brasil pós-Real. Pesquisa \& Debate, Vol. 13, 1, 2002.

FIGUEIREDO, Argelina Cheibub; LIMONGI, Fernando. Executivo e Legislativo na nova ordem constitucional. $2^{\mathrm{a}} \mathrm{ed}$. Rio de Janeiro, RJ: Editora FGV, 2001. . Instituições políticas e governabilidade: desempenho do governo e apoio legislativo na democracia brasileira. In: Carlos Ranulfo Melo; Manuel Alcântara Sáez (Orgs.). A Democracia Brasileira: balanço e perspectivas para o Século 21. Belo Horizonte, MG: Editora UFMG, 2007.

____ O Congresso e as Medidas Provisórias: abdicação ou delegação? Novos Estudos CEBRAP, No. 47, 1997.

FLIGENSPAN, Flávio Benevett. Uma visão global da economia brasileira durante a vigência do Plano Real: avanços impasses e um cenário de crescimento com exclusão. Indicadores Econômicos FEE, Vol. 26, 1, 1998.

GREMAUD, Amaury Patrick; VASCONCELLOS, Marco Antonio Sandoval de; TONETO JR. Rudinei. Economia Brasileira Contemporânea. $7^{a}$ ed. São Paulo, SP: Atlas, 2007.

LANZARINI CASA, Carlos Alberto. Dívida Interna, Inflação e Desinflação (1964-2004): o financiamento do Estado brasileiro sob a perspectiva da vulnerabilidade externa e da preferência pela liquidez 
do mercado de títulos públicos. Monografia (XIII Prêmio Tesouro Nacional, Tema "Política Fiscal e Dívida Pública", Terceiro Lugar) Tesouro Nacional, Poder Executivo, Brasília, 2008.

MACARINI, José Pedro. A Política econômica do Governo Sarney: os Planos Cruzado (1986) e Bresser (1987). Textos para Discussão, IE/UNICAMP, No. 157, 2009.

MAINWARING, Scott. Brasil: partidos débiles, democracia indolente. In: Scott Mainwaring; Timothy Scully (eds.). La construcción de instituciones democráticas: sistemas de partidos en América Latina. Santiago: CIEPLAN, 1996.

MODIANO, Eduardo. A ópera dos três Cruzados: 1985-1989. In: Marcelo de Paiva Abreu (Org.). A Ordem do Progresso: cem anos de política econômica republicana: 1889-1989. Rio de Janeiro, RJ: Editora Campus, 1990.

MORAES, Filomeno. A Constituição do Brasil de 1988 e a Reforma Política. Revista Jurídica da Presidência, Vol. 7, 72, 2005.

NUNES, Edson de Oliveira. A Gramática Política do Brasil: Clientelismo e Insulamento Burocrático. Rio de Janeiro, RJ/Brasília, DF: J. Zahrar Editor/Escola Nacional de Administração Pública, 1997.

RODRIGUES, Alberto Tosi. O Brasil de Fernando a Fernando: neoliberalismo, corrupção e protesto na política brasileira de 1989 a 1994. Ijuí, RS: Editora UNIJUí, 2000.

SIMONSEN, Mário Henrique. A inflação brasileira: lições e perspectivas. Revista de Economia Política, Vol. 5, 4, 1985.

TRIBUNAL SUPERIOR ELEITORAL (TSE). Resultados das Eleições de 1994. 2011. Disponível em: $<$ http://www.tse.jus.br/eleicoes/eleicoes- 
anteriores/eleicoes-1994/resultados-das-eleicoes-1994/resultados-daseleicoes-eleicoes-1994>. Acesso em: 20 de abril de 2016.

A influência da liderança política nos planos brasileiros de estabilização econômica: do Cruzado ao Real The influence of political leadership in Brazilian economic stabilization plans: from Cruzado to Real Submetido em: 2016-05-02 Aceito em: 2016-07-29 